\title{
Glycine site of the excitatory amino acid $N$-methyl-D-aspartate receptor in neonatal and adult brain
}

\author{
S W D'Souza, S E McConnell, P Slater, A J Barson
}

\begin{abstract}
The $\boldsymbol{N}$-methyl-D-aspartate (NMDA) receptor complex in brain is a glutamate receptor subtype with several recognition sites including a glycine site that is able to modulate and activate allosterically the receptor. This receptor may be important in the regulation of developmental synaptic plasticity. The release of glutamate and consequent overstimulation of NMDA receptors that follows hypoxia-ischaemia leads to brain damage. Brain tissue obtained at necropsy was studied in a total of 16 term infants aged less than 1 week to 22 weeks and in four adults aged from 66 to 84 years. Glycine sites were determined in brain sections by the binding of the selective ligand $\left[{ }^{3} \mathrm{H}\right] 5,7$-dichlorokynurenic acid and measured by autoradiography. In infant brains the amount of binding to the glycine site was higher in temporal cortex and hippocampus than in basal ganglia and was also higher than in comparable areas of adult brain. The amount of glycine site binding in infant cortex increased with postnatal age. The data suggest that infant brain acquires a relatively high density of NMDA receptors in temporal lobe due to postnatal proliferation of glutamatergic synapses. These findings have therapeutic implications as drugs that reduce NMDA receptor function by blocking the glycine modulatory site would be pertinent to preventing brain damage after hypoxia-ischaemia.

(Arch Dis Child 1993; 69: 212-215)
\end{abstract}

Glutamate, the major excitatory neurotransmitter, may be responsible for controlling some physiological processes in the developing brain including the regulation of neuronal survival, the production of synapses, and activity dependent synaptic plasticity. ${ }^{12}$ Glutamate influences neuronal development by activating specific receptors, principally the $N$-methyl-D-aspartate (NMDA) subtype. ${ }^{2-4}$

One of the most striking changes in the cerebral cortex during early postnatal development of the human brain is a rapid growth in dendritic processes and synapses, many of which are subsequently eliminated during childhood. 5 The idea that glutamatergic synapses increase postnatally is supported by neurochemical measurements on infant brains that found a postnatal increase in cortical and cerebellar glutamate uptake sites; these are markers for presynaptic glutamatergic nerve terminals. ${ }^{67}$ Further evidence of the role of glutamate in brain development would be gained by finding postsynaptic glutamate receptors which proliferate postnatally. The NMDA receptor is a candidate because research indicates it has key roles not only in the developmental actions of glutamate ${ }^{2}$ but also in the physiological mechanisms of learning and memory where glutamate has a pronounced role. ${ }^{89}$ Glutamate is also noted for causing excitotoxic damage in the brain and is released during hypoxia-ischaemia. The types of brain damage that follow episodes of ischaemia, hypoglycaemia, and protracted seizures have been attributed to overstimulation of glutamate receptors, including the NMDA receptor. ${ }^{10}$

Much is known about the NMDA receptor, which is recognised to be a complex structure with several recognition sites coupled to a cation channel. ${ }^{11}$ Calcium ions can enter nerve cells via the channel, which is normally blocked by magnesium ions at physiological resting membrane potentials. Partial depolarisation, which may be achieved by glutamate activating a different receptor, removes the magnesium block and allows glutamate to open calcium channels. The rise in intracellular calcium may have deleterious effects on nerve cells.

Recently a glycine site was uncovered which is part of the NMDA receptor complex but differs fundamentally from the usual central nervous system inhibitory glycine receptor in being insensitive to blockade by strychnine. ${ }^{12}$ Glycine is an obligatory 'coagonist' with glutamate ${ }^{13}$ and is able to potentiate allosterically NMDA responses. ${ }^{12} 14$ The minimum requirement for NMDA receptor-cation channel opening in vivo is probably activation of NMDA and glycine sites plus some membrane depolarisation to overcome the magnesium ion block. Our preliminary report suggested that infants may have more NMDA receptors than adults. ${ }^{15}$ Reduction in neurological and electroencephalographic abnormalities were reported in children with hyperglycinaemia after treatment with sodium benzoate, which lowered plasma glycine and dextromethorphan - this blocks the cation channel coupled to the NMDA receptor. ${ }^{1617}$ There is an ongoing search for therapeutic agents, including glycine antagonists, to reduce brain damage resulting from NMDA receptor activation. ${ }^{18}$ In the present study we investigated glycine sites in parts of temporal lobe and basal ganglia in infant brain and compared our findings with those in adult brain. 


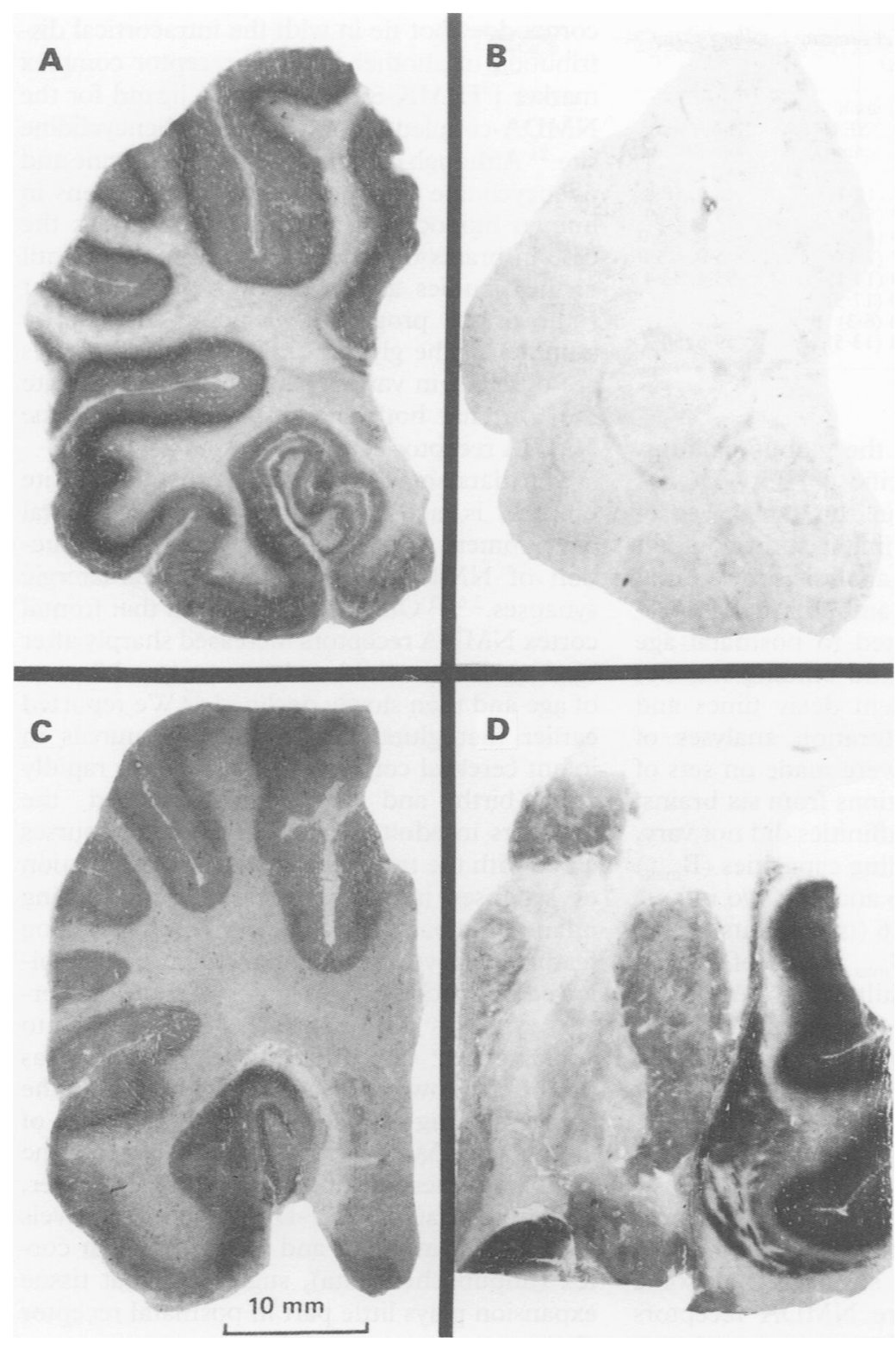

Figure $1 \quad \beta H] 5,7-D C K A$ binding autoradiographs. (A) Total binding of the ligand in temporal cortex and hippocampus: autoradiograph prepared from a section cut from the brain of an infant aged 20 weeks. (B) Non-specific binding in an identical section to $(A)$ measured with $100 \mu M$ glycine as displacer. (C) Total binding of $\beta$ H]5,7-DCKA in temporal cortex and hippocampus from brain of an adult aged 67 years. (D) Total binding of [3 H] 5,7-DCKA in a basal ganglia section from the brain of a 20 week infant. The darker the area the higher the ligand binding.

\section{Methods}

Coronal blocks of brain containing temporal lobe and basal ganglia were removed at necropsy. The infants were born at term and their ages at the time of death were less than 1 week to 20 weeks. Brain tissue was taken from four adults aged 66 to 84 years. Details of the subjects are given in table 1 . None of the brains had any apparent pathology. The tissues were quick frozen in isopentane at $-50^{\circ} \mathrm{C}$ and coronal sections were cut in a cryostat $(20 \mu \mathrm{m})$ and were thaw mounted on glass slides. Sections were labelled with $\left[{ }^{3} \mathrm{H}\right] 5,7$-dichlorokynurenic acid $\left(\left[{ }^{3} \mathrm{H}\right] 5,7-\right.$ DCKA), a potent and selective antagonist of the NMDA receptor strychnine insensitive glycine site. ${ }^{19}$ The sections were first given two preincubations $(45 \mathrm{~min})$ in $50 \mathrm{mM}$ Tris acetate buffer $(\mathrm{pH} 8.0)$ with drying in between followed by incubation in Tris buffer containing either a fixed concentration $(10 \mathrm{nM})$ or one
Table 1 Details of the subjects

\begin{tabular}{|c|c|c|c|}
\hline Age & No & $\begin{array}{l}\text { Death to brain } \\
\text { freezing (hours) }\end{array}$ & Diagnosis \\
\hline \multicolumn{4}{|c|}{ Infants (weeks) } \\
\hline$<1$ & 3 & $48,24,72$ & $\begin{array}{l}\text { Subdural haemorrhage } \\
(\mathrm{n}=1), \text { multiple } \\
\text { anomalies }(\mathrm{n}=2)\end{array}$ \\
\hline 5 & 2 & 24,48 & SIDS \\
\hline 8 & 2 & 24,24 & $\begin{array}{l}\text { SIDS }(n=1) \text {, interstitial } \\
\text { pneumonitis }(n=1)\end{array}$ \\
\hline & 1 & & SIDS \\
\hline 12 & 4 & $28,48,24,24$ & $\begin{array}{l}\text { Interstitial pneumonitis } \\
(n=1), \text { SIDS }(n=3)\end{array}$ \\
\hline 18 & 1 & 24 & SIDS \\
\hline 20 & 2 & 24,24 & SIDS \\
\hline \multirow{2}{*}{\multicolumn{4}{|c|}{ Adult (years) }} \\
\hline & & & \\
\hline 66 & 1 & & \\
\hline 74 & 2 & $36 \cdot 5,11$ & $\begin{array}{l}\text { LVF }(n=1) \text {, pulmonary } \\
\text { embolism }(n=1)\end{array}$ \\
\hline 84 & 1 & 9 & LVF \\
\hline
\end{tabular}

SIDS = sudden infant death syndrome, $\overline{L V F}=$ left ventricular failure.

of nine concentrations between $0.44 \mathrm{nM}$ and $115 \mathrm{nM}$ (for saturation binding) of $\left[{ }^{3} \mathrm{H}\right] 5,7-$ DCKA $(18 \cdot 2 \mathrm{Ci} / \mathrm{mmol})$ for 15 minutes at $4^{\circ} \mathrm{C}$. Duplicate sections were incubated as described with the addition of $100 \mu \mathrm{M}$ glycine to measure the non-specific binding. Sections were washed twice for 10 seconds in 1 litre volumes of buffer at $4^{\circ} \mathrm{C}$, dipped in cold distilled water to remove buffer salts and dried. The sections were exposed to tritium film at $4^{\circ} \mathrm{C}$ for 16 weeks with tritium autoradiography standards (Microscales, Amersham). Optical density measurements were made on the autoradiographs and the standards with an image analyser. One area measurement was made on four total binding autoradiographs and two on non-specific binding autoradiographs. Absolute $\left[{ }^{3} \mathrm{H}\right] 5,7$-DCKA binding values $(\mathrm{fmol} / \mathrm{mg}$ tissue, in keeping with Microscales which are calibrated in terms of tissue weight) were obtained from standard curves of optical density versus ligand binding. Saturation binding data from representative brains were calculated by Scatchard analysis.

\section{Results}

A high proportion of the total $\left[{ }^{3} \mathrm{H}\right] 5,7-\mathrm{DCKA}$ bound to brain sections was displaced by excess glycine (fig 1). For example, the specific (displaceable) $\left[{ }^{3} \mathrm{H}\right] 5,7-\mathrm{DCKA}$ binding in temporal cortex (parahippocampal gyrus, Brodmann's area 28 ) was $72 \%$ of the total binding in the brain of a 20 week infant and $82 \%$ in a 22 week infant. These findings show that most of the $\left[{ }^{3} \mathrm{H}\right] 5,7-\mathrm{DCKA}$ binding was to the specific glycine site.

The autoradiographs showed pronounced regional differences in the amount of $\left[{ }^{3} \mathrm{H}\right] 5,7-$ DCKA bound to brain sections (illustrated in fig 1). The distribution of $\left[{ }^{3} \mathrm{H}\right] 5,7-\mathrm{DCKA}$ binding within the temporal cortex was uneven, especially in infant brain sections, with deep layers of the cortex having high glycine site binding.

The $\left[{ }^{3} \mathrm{H}\right] 5,7-\mathrm{DCKA}$ quantitative binding data measured on the autoradiographs (table 2) show that in rank order the cortex and hippocampus of infant brain contained the most $\left[{ }^{3} \mathrm{H}\right] 5,7-D C K A$ binding. In the basal ganglia the caudate and putamen had more 
Table 2 Specific [ ${ }^{3}$ ] 5,7-DCKA binding fmolmg tissue in areas of infant and adult brains

\begin{tabular}{lcc}
\hline & $\begin{array}{l}\text { Infant brain } \\
\text { (mean (SEM) of } \\
12-16 \text { infants) }\end{array}$ & $\begin{array}{l}\text { Adult brain } \\
(n=2)\end{array}$ \\
\hline Brain area & $41 \cdot 7(12 \cdot 1)$ & $48 \cdot 0,58 \cdot 4$ \\
Caudate nucleus & $38 \cdot 2(5 \cdot 2)$ & $53 \cdot 1,53 \cdot 9$ \\
Putamen & $10 \cdot 9(4 \cdot 2)$ & $<5 \cdot 0,<5 \cdot 0$ \\
Globus pallidus & $37 \cdot 7(7 \cdot 4)$ & $<5 \cdot 0,<5 \cdot 0$ \\
Ventral thalamus & $61 \cdot 9(14 \cdot 1)$ & $53 \cdot 4,53 \cdot 4$ \\
Amygdala & $110 \cdot 9(17 \cdot 5)$ & - \\
Hippocampus & $145 \cdot 3(8 \cdot 3)$ & - \\
Temporal cortex BA41 & $133 \cdot 4(13 \cdot 5)$ & $59 \cdot 6,50 \cdot 2$ \\
Temporal cortex BA22 & & \\
BA=Brodmann's area. & &
\end{tabular}

glycine site binding than the globus pallidus.

The amounts of specific $\left[{ }^{3} \mathrm{H}\right] 5,7-\mathrm{DCKA}$ binding were measured in the same area of temporal cortex from 16 infant and two adult brains (fig 2). Regression analysis showed that in the infant brains the amount of $\left[{ }^{3} \mathrm{H}\right] 5,7-$ DCKA binding was related to postnatal age $(r=0.5324, \mathrm{p}=0.03)$. Ligand binding was not correlated with postmortem delay times and tissue storage times. Saturation analyses of $\left[{ }^{3} \mathrm{H}\right] 5,7-D C K A$ binding were made on sets of serial temporal cortex sections from six brains. Although ligand binding affinities did not vary, the maximum ligand binding capacities $\left(B_{\max }\right)$ in fmol/mg tissue were 56 and 66 (two infants $<1$ week) and 219 and 226 (two infants age 12 weeks), compared with $B_{\max }$ values of 63 and $125 \mathrm{fmol} / \mathrm{mg}$ tissue in adult brains. Although these data are insufficient for statistical evaluation, they appear to show a postnatal increase in the numbers of glycine sites in infants.

\section{Discussion}

We have found pronounced regional differences in the amounts of glycine site binding in developing brain, which suggests that some brain areas produce more NMDA receptors and therefore have more glutamatergic synapses than others. For example, low $\left[{ }^{3} \mathrm{H}\right] 5,7-\mathrm{DCKA}$ binding in globus pallidus compared with caudate nucleus and putamen is consistent with the globus pallidus normally having few if any glutamatergic nerve terminals apart perhaps from a transient perinatal innervation..$^{20}$ In contrast, the conspicuously high binding of $\left[{ }^{3} \mathrm{H}\right] 5,7-$ DCKA in the deep layers of infant cortex and a similar tendency towards heterogeneity in adult

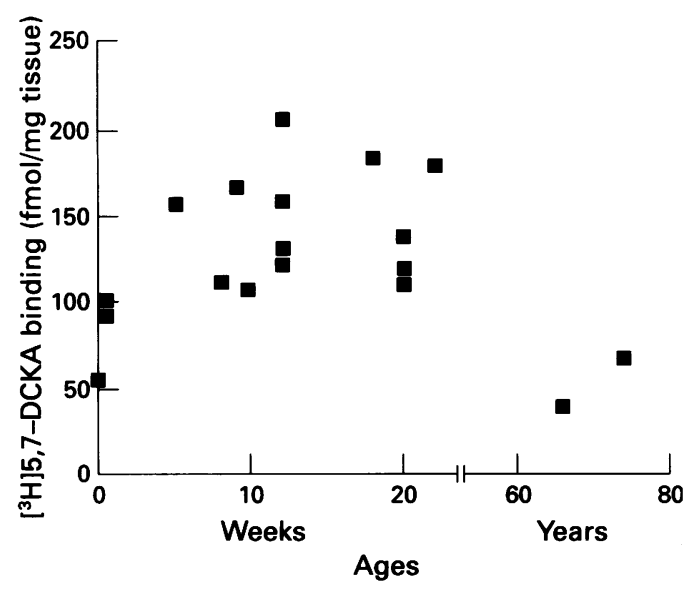

Figure 2 The specific binding of $\left.{ }^{3} H\right] 5,7-D C K A$ in temporal cortex from individual infant and adult brains. cortex does not tie in with the intracortical distribution of another NMDA receptor complex marker $\left[{ }^{3} \mathrm{H}\right] \mathrm{MK}-801$, which is a ligand for the NMDA-coupled ion channel phencyclidine site. ${ }^{21}$ Although others reported that glycine and phencyclidine sites had similar distributions in human hippocampus, ${ }^{22}$ this is not always the case in brains of experimental animals. ${ }^{23}$ Until further studies are made, it is probable that some of the properties including the relative affinities of the glycine and phencyclidine sites are different in various parts of brain ${ }^{24}$ despite the fact that both sites are part of the same NMDA receptor complex.

Our data show that much of the glycine site binding is acquired during early postnatal development and coincides with the production of NMDA receptors and glutamatergic synapses. $^{2615}$ Other workers found that frontal cortex NMDA receptors increased sharply after birth, peaked in children between 1 and 2 years of age and then slowly declined..$^{25}$ We reported earlier that glutamatergic nerve terminals in infant cerebral cortex began to develop rapidly after birth and eventually exceeded the numbers in adult cortex. ${ }^{6}$ These time courses agree with the timing of the general production of synapses in many parts of brain during infancy and early childhood, which is a striking feature of developing human brain and is followed by much slower pruning of some exuberant synapses through later childhood into adolescence. ${ }^{5}$ Of course, tissue expansion as the brain grows may affect our data and the higher binding of $\left[{ }^{3} \mathrm{H}\right] 5,7-\mathrm{DCKA}$ in cortex of infants compared with adults could be the result of closer packing of neurons. However, we found that $\left[{ }^{3} \mathrm{H}\right] 5,7-D C K A$ binding levels were similar in infant and adult cerebellar cortex (unpublished data), suggesting that tissue expansion plays little part in postnatal receptor changes.

Given the limitations of delay in obtaining brain tissue after death and subsequently storing it at low temperature, our results reflect the ontogeny of NMDA receptors with a glycine binding site. Some loss of receptors may have taken place after death but this was reduced by obtaining brain tissue at necropsy within 72 hours of death. ${ }^{26}$ Further receptor loss by lengthy storage at $-70^{\circ} \mathrm{C}$ has been ruled out, ${ }^{27}$ and the results reported have confirmed our (unpublished) observations that receptor numbers and affinity are not significantly affected. None of the brain tissue kept in our 'bank' is stored longer than two years.

We have considered two further sources of error in our observations on receptor binding that might have influenced developmental changes: first, differences in myelination between age groups, and second, prolonged hypoxic-ischaemic insult in individuals who died. Differences in myelination are to be expected but no attempt was made to compensate for 'tritium quenching' in white matter as measurements were taken in grey matter only. The case history and necropsy findings were reviewed in each subject whose brain tissue was studied. As there was no evidence of prolonged hypoxia-ischaemia it is unlikely that 
a similar insult had caused acute changes in receptor binding.

The present findings suggest that the concentration of NMDA receptors is greater in infant than in adult brain temporal cortex and there are pronounced regional differences between temporal cortex, hippocampus, and basal ganglia in infant brain. As developing brain has high glycine site binding it may turn out that infants are highly responsive to glycine antagonists, which may therefore be valuable as neuroprotective agents in the management of babies recovering from birth asphyxia. In experimental studies such compounds attenuated brain damage produced by excess NMDA activation due to hypoxia-ischaemia in neonatal rats. ${ }^{28}$ Further studies are required to investigate whether in infant brain NMDA receptor density equates with the severity and distribution of hypoxic-ischaemic, hypoglycaemic, or seizure related damage.

There is a search for therapeutic agents which can alter NMDA receptor function and agents affecting the glycine site and the phencyclidine site (dizocilpine, MK-801) of this receptor are prime candidates. In a previous report we presented data on MK-801 binding in developing brain from 20 weeks after term to adult life. ${ }^{15}$ Substances active at the phencyclidine site including $\mathrm{MK}-801$ are seen as potential anti-ischaemia agents ${ }^{29}$ but their psychotomimetic actions in man may restrict their use. Glycine site antagonists may reduce NMDA receptor function and several glycine site antagonists have been described including kynurenic acid, 7-chlorokynurenic acid, and HA-966. ${ }^{30}$ The combined glycine and NMDA receptor regulation of the NMDA channel in neurones was suggested to be like a two key lock where both sites are needed to open the channel to cations. ${ }^{31}$ Therefore like MK-801 the glycine site antagonists are seen as having therapeutic potential in limiting brain damage after cerebral ischaemia. ${ }^{29} 32$ The need to investigate the use of such drugs in future is illustrated by data showing that with present management of neonatal hypoxicischaemic encephalopathy the proportions handicapped in later childhood in moderate and severe cases are $25 \%$ and $75 \%$ respectively. ${ }^{33}$

We thank Action Research for financial support.

1 Drian MJ, Kamenka JM, Pirat JL, Privat A. Non competitive antagonists of NMDA prevent spontaneous neuronal death in primary cultures of embryonic cortex. $\mathcal{F}$ Neurosci Res 1991; 29: 133-8.

2 McDonald JW, Johnston MV. Physiological and pathophysiological roles of excitatory amino acids during central nervous system development. Brain Research Reviews 1990; 15: 41-70.

3 Balazs R, Jorgensen OS, Hack N. N-methyl-D-aspartate promotes the survival of cerebellar granule cells in culture. Neuroscience 1988; 27: 437-51.

4 DuPont J, Gardette R, Crepel F. Postnatal development of the chemosensitivity of rat cerebellar Purkinje cells to excitatory amino acids. Brain Res 1987; 431: $59-68$

5 Huttenlocher PR. Morphometric study of human cerebral cortex development. Neuropsychologia 1990; 28: 517-27.

6 Slater P, McConnell S, D'Souza SW, Barson AJ, Simpson MDC, Gilchrist AC. Age-related changes in binding to excitatory amino acid uptake site in temporal cortex of $157-60$.
7 Slater P, McConnell S, D'Souza SW, Barson AJ. Age-related changes in binding to excitatory amino acid uptake sites in human cerebellum. Brain Res 1992; 579: uptake sites 26 .

8 Lynch MA, Errington ML, Bliss TP. Long-term potentiation and the sustained increase in glutamate release which follow tetanic stimulation of the perforant path are both blocked by D(-)aminophosphonovaleric acid. Neuroscience Abstracts 1985; 11: 834 .

9 Collingridge GL, Bliss TVP. NMDA receptors - their role in long-term potentiation. Trends Neurosci 1987; 10: 288-93.

10 Choi DW, Rothman SM. The role of glutamate neurotoxicity in hypoxic-ischemic neuronal death. Annu Rev Neurosci 1990; 13: 171-82.

11 Collingridge GL, Lester R. Excitatory amino acid receptors in the vertebrate nervous system. Pharmacol Rev 1989; 40: in the vertebr

12 Johnson JW, Ascher P. Glycine potentiates the NMDA response in cultured mouse brain neurons. Nature 1987; 325: 529-31

13 Kleckner NW, Dingledine R. Requirement for glycine in activation of NMDA-receptors expressed in xenopus oocytes. Science 1988; 241: 835-7.

14 Monahan JB, Corpus VM, Hood WF, Thomas JW, Compton RP. Characterization of a $\left[{ }^{3} \mathrm{H}\right]$ glycine recognition site as a regulatory site of the $\mathrm{N}$-methyl-D-aspartate receptor complex. F Neurochem 1989; 53: $370-5$.

15 D'Souza SW, McConnell SE, Slater P, Barson AJ. $\mathrm{N}$-methyl-D-aspartate binding sites in neonatal and adult brain. Lancet 1992; 339: 1240

16 Oliya Y, Ochi N, Mizutani N, Ilayakawa C, Watanabe K. Non-ketotic hyperglycinaemia: treatment with NMDA antagonist and consideration of neuropathogenesis. Pediatr Neurol 1991; 7: 65-8.

17 Hamosh A, McDonald JW, Valle D, Francomano CA, Niedermeyer E, Johnston MV. Dextromethorphan and high-dose benzoate therapy for nonketotic hyperglycinemia in an infant. F Pediatr 1992; 121: 131-5.

18 Albers GW. Potential therapeutic uses of N-methyl-Daspartate antagonists in cerebral ischemia. Clin Neuropharmacol 1990; 13: 177-97.

19 Baron BM, Siegel BW, Slone AL, Harrison BL, Palfreyman $M G$, Hurt SD. $\left[{ }^{3} \mathrm{H}\right] 5,7$-dichlorokynurenic acid, a novel radioligand labels NMDA receptor-associated glycine binding sites. Eur $\mathcal{f}$ Pharmacol 1991; 206: 149-54.

20 Greenamyre T, Penney JB, Young AB, Hudson C, Silverstein FS, Johnston MV. Evidence for transient perinatal glutamatergic innervation of globus pallidus. f Neurosci 1987; 7: 1022-30.

21 Shaw PJ, Ince PG, Johnson M, Bates D, Cartlidge NEF. An autoradiographic study of N-methyl-D-aspartate and motor neuron disease. $\mathcal{f}$ Neurol Neurosurg Psychiatry 1992; 55: 240.

22 Jansen KLR, Draunow M, Faull RLM. [ $\left.{ }^{3} \mathrm{H}\right]$ Glycine binding sites, NMDA and PCP receptors have similar distributions in the human hippocampus: an autoradiographic study. Brain Res 1989; 482: 174-8.

23 Maragos WF, Penney JB, Young AB. Anatomic correlation of NMDA and $\left[{ }^{3} \mathrm{H}\right] \mathrm{TCP}$-labeled receptors in rat brain. I Neurosci 1988; 8: 493-501.

24 O'Shea RD, Manallack DT, Conway EL, Mercer LD, Beart PM. Evidence for heterogenous glycine domains but conserved multiple states of the excitatory amino acid recognition site of the NMDA receptor: regional binding studies with $\left[{ }^{3} \mathrm{H}\right]$ glycine and $\left[{ }^{3} \mathrm{H}\right] \mathrm{L}$-glutamate. Exp Brain Res 1991; 86: 652-62.

25 Kornhuber J, Retz W, Riederer P, Heinsen H, Fritze J. Effect of antemortem and postmortem factors on $\left[{ }^{3} \mathrm{H}\right]$ glutamate binding in the human brain. Neurosci Lett 1988; 93: 312-7.

26 Whitehouse PJ, Lynch D, Kuhar MJ. Effects of postmortem delay and temperature on neurotransmitter receptor binding in a rat model of the human autopsy process. ing in a rochem 1984; 43: 553-9.

27 Piggott MA, Perry EK, Perry RH, Court JA. $\left[{ }^{3} \mathrm{H}\right] \mathrm{MK}-801$ binding to the NMDA receptor complex, and its modulation in human frontal cortex during development and aging. Brain Res 1992; 588: 277-86.

28 Uckele JE, McDonald JW, Johnston MV, Silverstein FS. Effect of glycine and glycine receptor antagonists on NMDA-induced brain injury. Neurosci Lett 1989; 107: 279-83.

29 Albers GW, Goldberg MP, Choi DW. N-methyl-D-aspartate antagonists: ready for clinical trial in brain ischemia? Ann Neurol 1989; 25: 390-403.

30 Wood PL, Emmett MR, Rao TS, Mick S, Cler J, Iyengar S. In vivo modulation of the N-methyl-D-aspartate receptor complex by D-serine: potentiation of ongoing neuronal activity as evidenced by increased

31 Bonhaus DW, Yeh GC, Skaryak L, McNamara JO. Glycine regulation of the $\mathrm{N}$-methyl-D-aspartate receptor-gated ion channel in hippocampal membranes. Mol Pharmacol 1989; 36: 273-9.

32 Pulsinelli W. Pathophysiology of acute ischaemic stroke. Lancet 1992; 339: 533-6.

33 Levine MJ, Sands C, Grindulis H, Moore JR. Comparison of two methods of predicting outcome in perinatal asphyxia. Lancet 1986; i: 91. 